Research article

\title{
DISASTER MANAGEMENT IN TURKEY: A SPATIAL APPROACH
}

\author{
Adem Öcal ${ }^{*}$ \\ ${ }^{1}$ Independent Researcher, Ankara / Turkey \\ * Correspondence: ocadem@gmail.com \\ Received: 10 April; Accepted: 20 May; Published: 30 June
}

\begin{abstract}
Disasters cause losses on people and residential areas, cause interruption of normal life and decision-making mechanism, collapse communication and communication even for a short time, and damage infrastructure and superstructure investments. In the traditional disaster management design, the regulations created by the legislation and rules issued are directed to each unit in the country at the same time. Administrative authorities must coordinate the emergency recovery process as a requirement of these protocols. In modern disaster management approaches, disasters are associated with spatially; the distribution, severity, type, and population affected by disasters are all considered. Starting with the spatial distribution of such disasters in Turkey, disaster management can be structured from space to center. The Turkish disaster management mechanism has issued recommendations as a consequence of this study.
\end{abstract}

Keywords: spatial approach, disaster, disaster management, earthquake, Turkey.

\section{Introduction}

All phases of disaster response, recovery, recovery, mitigation, and disaster preparedness that happen after one disaster event and continue until the next disaster (Coppola, 2011: 10) are included in the disaster management process (Fig 1). The main objectives of the response phase are to provide emergency aid and assistance, reduce the risk of secondary damage, and allow rescue operations as easy as possible. "Provide immediate assistance during the early recovery phase required to restore critical life support services to minimal operating levels, and continue to provide support until society returns to normal," according to the recovery plan (Petak, 1985). Mitigation is an opportunity to lessen the potential effects of disasters when they occur. Behaviours of preparedness for potential disasters are also included in preparedness. 


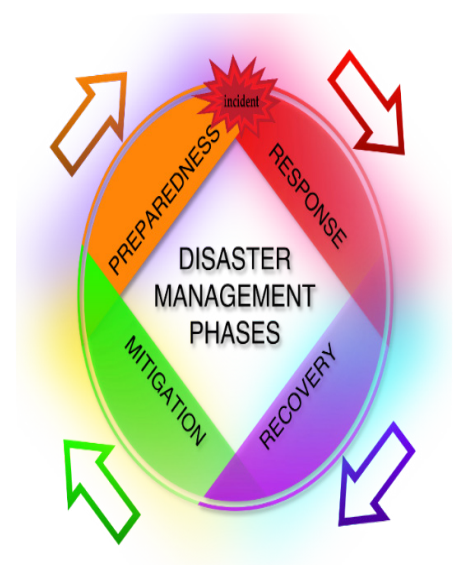

Figure 1. Disaster management process

Comprehensive, progressive, risk-driven, integrated, collaborative, coordinated, flexible, and professional disaster management can be structured (Çakın, 2007). Priorities, hazards, risk analysis, impact analysis, alert, and forecasting are all critical factors to consider in risk-driven disaster management. On the other hand, integrated disaster management focuses on bringing together all levels of management (central administration and local municipalities), social units, the private sector, NGOs, and individuals.

An uncoordinated emergency and crisis management system can be much less effective than a coordinated disaster / risk management perspective in handling disasters and emergencies. The interruption or prevention of normal life, as well as the unpredictable and uncontrollable nature of disaster risks, are the main factors that increase the severity of disasters (Kapucu, 2013: Coppola, 2011). The works done before and after a catastrophe is referred to as disaster management. Since a disaster just lasts a short time, the work that can be performed during it is a repetition of exercises that have already been practiced and implemented.

Crises, threats, and tragic incidents draw the public's and media's attention rapidly because they impact large groups of people directly or indirectly. Following such events, public policies in a part of the whole of the can alter (Alexander, 2005). These adjustments differ depending on the countries' governance understanding and disaster characteristics; often a centralized structure is more beneficial, and other times it is more beneficial to interfere locally in disaster areas (Yavaş \& Yavuz, 2015).

Since public organizations and local municipalities lack the capacity, resources, and experience required for disaster management on their own, collaboration between public institutions, the private sector, and non-governmental organizations is required for the effective completion of the disaster management process's tasks. Major disasters have shown the importance of collaboration among all organizations and NGOs involved in disaster management for successful disaster management.

In disaster management around the world, a transformation from post-disaster wounding policies to pre-disaster preparedness and mitigation stages has been observed since the 1980s (Balamir, 2007: 32). The United Nations prepared the Hyogo Declaration for the years 2005-2015 and the Sendai Declarations for the years 2015-2030 with the aim of identifying disaster risks, preventing disasters before they happen, and preparing individuals and organizations for disasters (Macit, 2019; Pearson \& Pelling, 2015). Since no perfect crisis management mechanism exists in all countries, governments are forced to pursue solutions that will improve their ability to deal with crises. 


\section{The current disaster management system in Turkey}

Turkey has been adhering to the Disaster Emergency Response Services Regulation (AADMHY) in terms of disaster preparedness and damage prevention since 2013. As a result, the Turkish Republic Ministry of Interior's Crisis and Emergency Management Presidency (AFAD) takes disaster-prevention measures (Şahin, 2019). As can be deduced from this concept, Turkey's disaster management center operates as a single-source service (Table 1). Taking decisions as the centre of the whole country in disaster management may lead to the emergence of wrong practices in the disaster area, to react slowly, and the local response of the decisions taken to be irrational. Especially when it is considered that not all cities have the same level of regular structuring, the disconnection between decision-makers and the application area increases (Yavaş \& Yavuz, 2015). Leaving decision-making power solely in the hands of local authorities and making emergency management decisions on the spur of the moment can, however, result in a misreading of the big picture. Today, an integrated disaster management system is used to identify the hazards and threats ahead of time, to take steps to avoid or mitigate losses that could occur prior to the disaster, to ensure successful intervention and coordination, and to carry out post-disaster recovery works in a timely and efficient manner (AFAD, 2021).

Table 1. The Turkish disaster management system's major milestones

(Kuterdem, 2010; Seymen\&Akın, no date).

\begin{tabular}{|c|c|c|}
\hline Period & Properties & Annotations \\
\hline-1923 & Before Republican & Rules for settlements in Istanbul \\
\hline $1923-1944$ & & Response, Post Disaster Aids and 1930 Municipality Law \\
\hline $1944-1958$ & & $\begin{array}{l}\text { Partially Disaster Reduction, First EQ Zonning Map, } \\
\text { First Building Code }\end{array}$ \\
\hline $1959-1999$ & & $\begin{array}{l}\text { Ministry of Reconstruction and Settlement, } \\
\text { Civil Defence Law }\end{array}$ \\
\hline $1999-2009$ & Awakenning & \\
\hline $2009-2013$ & Organisation & $\begin{array}{l}\text { Establishing Disaster and Emergency Management } \\
\text { Presidency (AFAD) }\end{array}$ \\
\hline $2013-2018$ & Re- organisation & $\begin{array}{l}\text { Regulation on Disaster and Emergency Response } \\
\text { Services }\end{array}$ \\
\hline $2018-$ & Re- organisation & $\begin{array}{l}\text { AFAD was connected to the Turkish Republic Ministry } \\
\text { of Interior's. }\end{array}$ \\
\hline
\end{tabular}

In Turkey, local governments are generally expected to carry out disaster preparedness as a legal requirement (Öcal, 2007). The Turkish crisis management system is structured in a hierarchical order. In the centralized management approach, legislation is the official basis for responding to disasters. Following Turkey's extreme disasters, the majority of disaster-related legislation was created. The Marmara Earthquake in Turkey in 1999, for example, caused concern, and the UN initiated risk management strategies, preparing the groundwork for a shift in Turkey's disaster management system. These provisions include the type of response to potential disasters, as well as the food supply, clothing, health services, and temporary shelter during and after the disaster (Ganapati, 2008). 


\section{Natural disaster risks and spatial approach to Turkey' disaster management}

Turkey is one of the few countries in the world that has been hit by many catastrophic events. Natural disasters, terrorist attacks, and migration caused by insecurity in neighboring countries are among the country's most common disasters. Due to its mathematical and specific location, Turkey has been seen in a wide variety of disasters, with the geological structure and climate playing a big role. A number of factors affect the severity of disasters that have arisen in the historical process of socioeconomic, cultural, and philosophical contexts. Individual and social inequalities in Turkey and its neighbors have the potential to have much further consequences. Turkey should establish a disaster management system to determine the relationship between all of the components mentioned above.

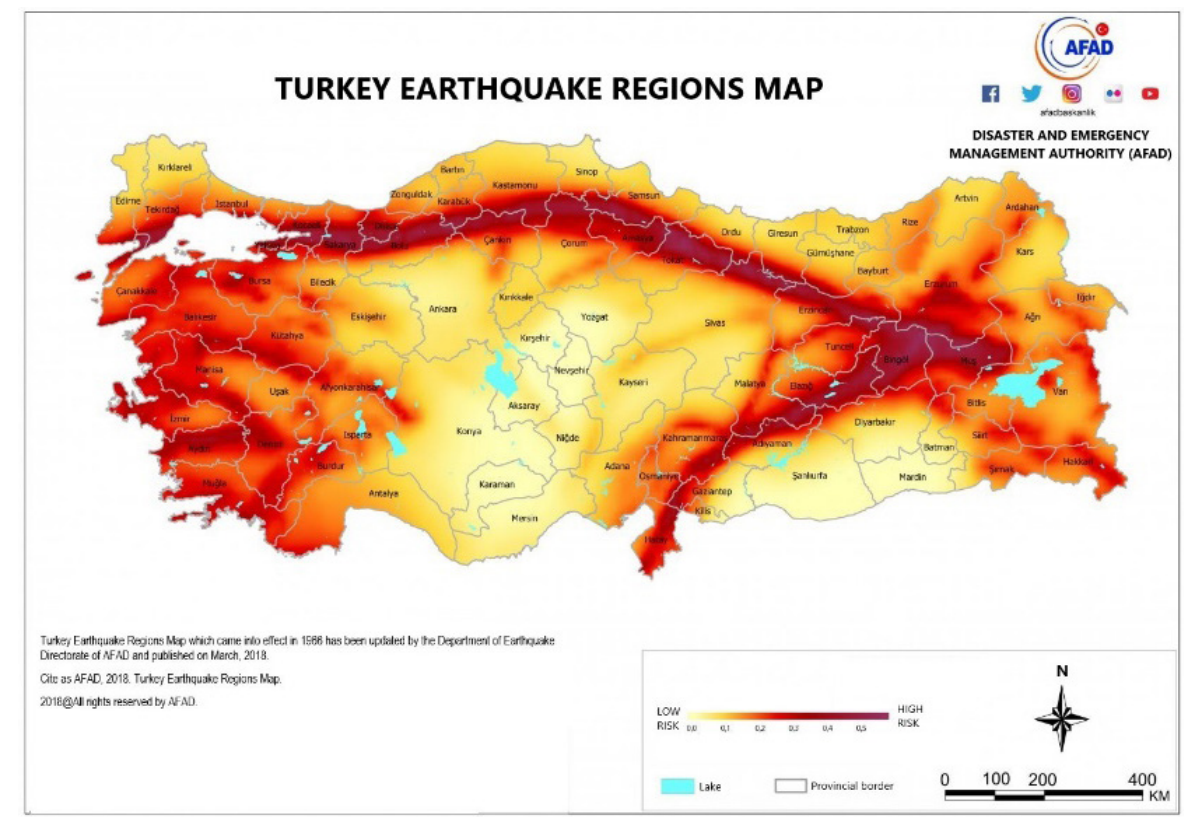

Figure 2. Turkey seismic regions (AFAD, 2018).

Because of its geographical location, Turkey is continuously threatened by natural disasters. Our country has experienced disasters such as earthquakes, landslides, floods, avalanches, drought, wildfires, extreme winter conditions, and storms. The landslide is the most common type of disaster in Turkey $(32,7 \%)$. Besides that, since Turkey is a geologically young country, earthquakes are common (6,8\%). In Turkey, floods are a major natural disaster $(12,2$ $\%)$. Avalanche is another form of disaster that occurs in our country $(3,8 \%)$, and can happen in Turkey, especially in the eastern part of the country. Occasionally, many natural disasters occur at the same time. Other natural hazards, such as severe weather conditions $(1,7 \%)$, are also seen in Turkey [AFAD, 2021]. Turkey is located on one of the world's most important fault zones. These fault lines can be found in three major areas: the North Anatolia Fault Zone (NAFZ), the South East Anatolia Fault Zone (SEAFZ), and the West Anatolia Fault Zone (Figure 2). Extreme and deadly earthquakes are produced by these fault generations.

In the 5472 settlements in Turkey (provincial, district centers, towns, municipalities, and villages), $15.3 \%$ of the landslides are observed. $43.5 \%$ of landslide-prone settlements are less than 20 kilometers from faults or fault areas (Figure 3). In other words, the faults/fault zones provided a suitable area for the production of landslides (Gökçe, Özden \& Demir, 2008). 


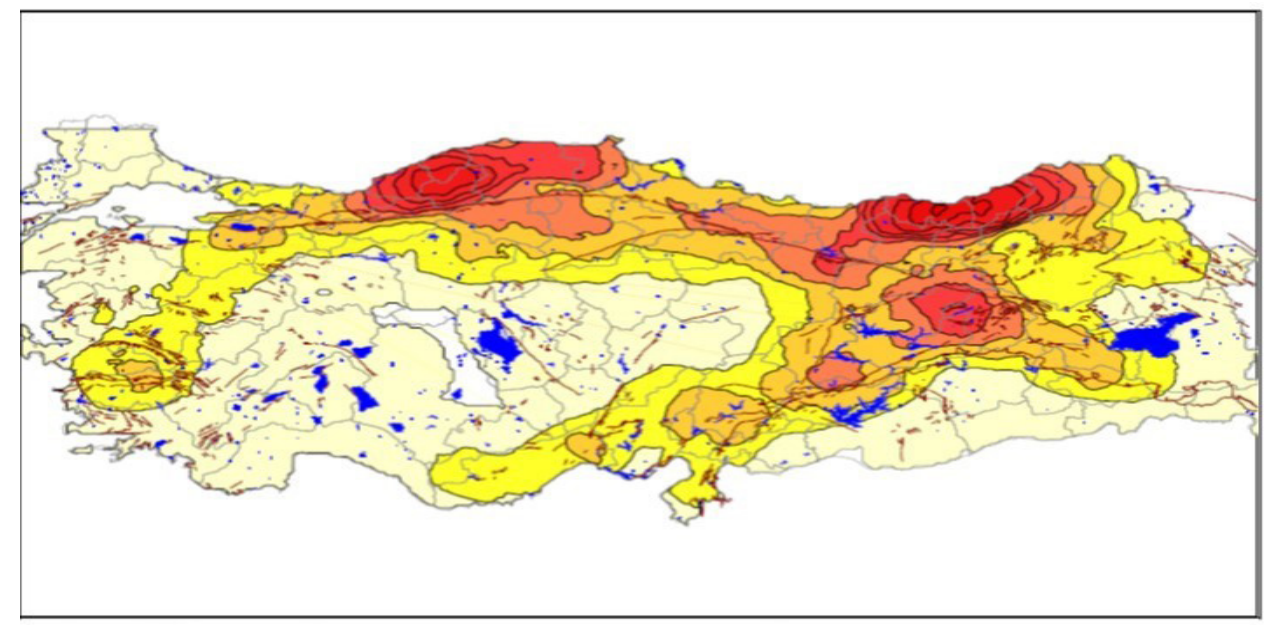

Figure 3. Lanslides and active faults in Turkey (Gökçe, Özden, Demir, 2008)

Turkey also has three different climates: Mediterranean, Continental, and Black Sea climates (similar to the Oceanic climate type). The majority of the country, especially the central and eastern Anatolia regions, has a continental temperate climate, while the Aegean, Mediterranean, and Southeastern Anatolia regions have subtropical dry summer climate characteristics, according to the Köppen-Trewartha climate classification. While the Black Sea coast has a subtropical humid climate; some provinces in Trakia and the Inner Aegean have a marine temperate climate (Fig. 4). In the provinces of Iğdır, Konya-Ereğli, Urfa-Ceylanpınar, and Çorum/Osmancık, semi-arid steppe climates can be observed. According to the Köppen-Trewartha Climate Classification, 47,22 of our country has a Continental Climate (Dc), 30.95 \% Subtropical Dry Summer Climate (Mediterranean climate - Cs), $11.51 \%$ Temperate Maritime (Do), 7.94 \% Subtropical Humid Climate (Cf), and $2.38 \%$ Semi-AridStep Climate (BF). Turkey is also confronted by major world air masses (Siberia HP, Asor HP, Island LP, and Basra LP). Within a year in Turkey, you can experience four separate seasons (Öcal, 2019).

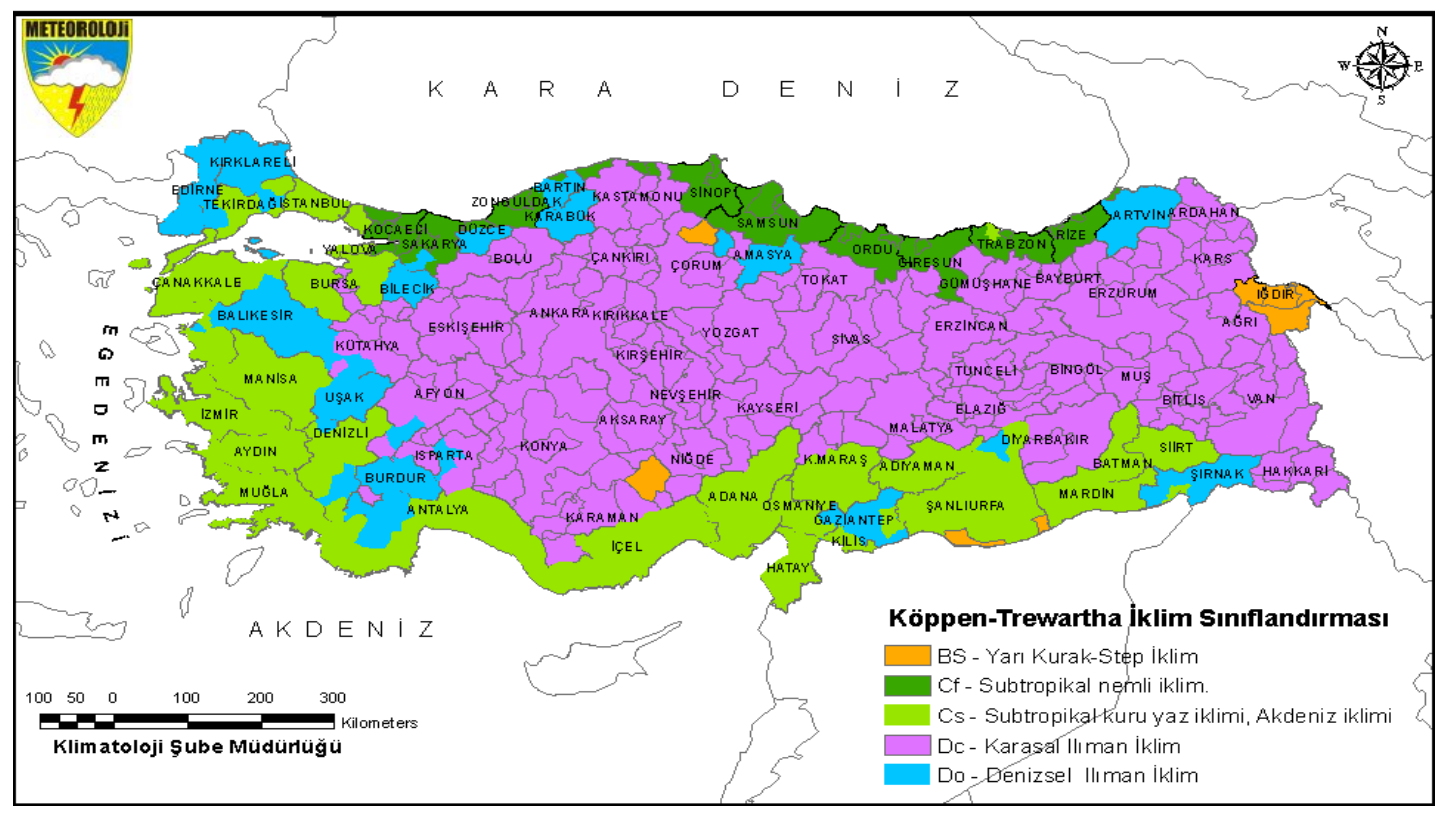

Figure 4. Koppen-Trewartha climate classification of Turkey (MGM, 2018) 
While Turkey has a wide range of climatic and geological features, earthquakes are the most destructive types of disasters in the country. For many years, earthquakes have been regarded as an interference in crisis management, and changes were made accordingly. As a result of this situation, the Turkish Crisis Management System was not flexible enough to deal with all potential crises.

An uniform disaster management system would be useful if Turkey ignored the broad geographic features and differentiation factors that cause disasters. For example, the Erzincan earthquake of 1939 (MS: 7.9) killed 32968 people, and the earthquake of 1992 killed 653 people (MS: 6.8). Karaman, on the other hand, has never been exposed to a severe earthquake. For another example, landslides are most prevalent in the provinces of Trabzon and Rize. These cities, on the other hand, are seismically secure. Erzurum and Sivas are popular for their floods, and Erzurum is a seismically risky place from these regions.

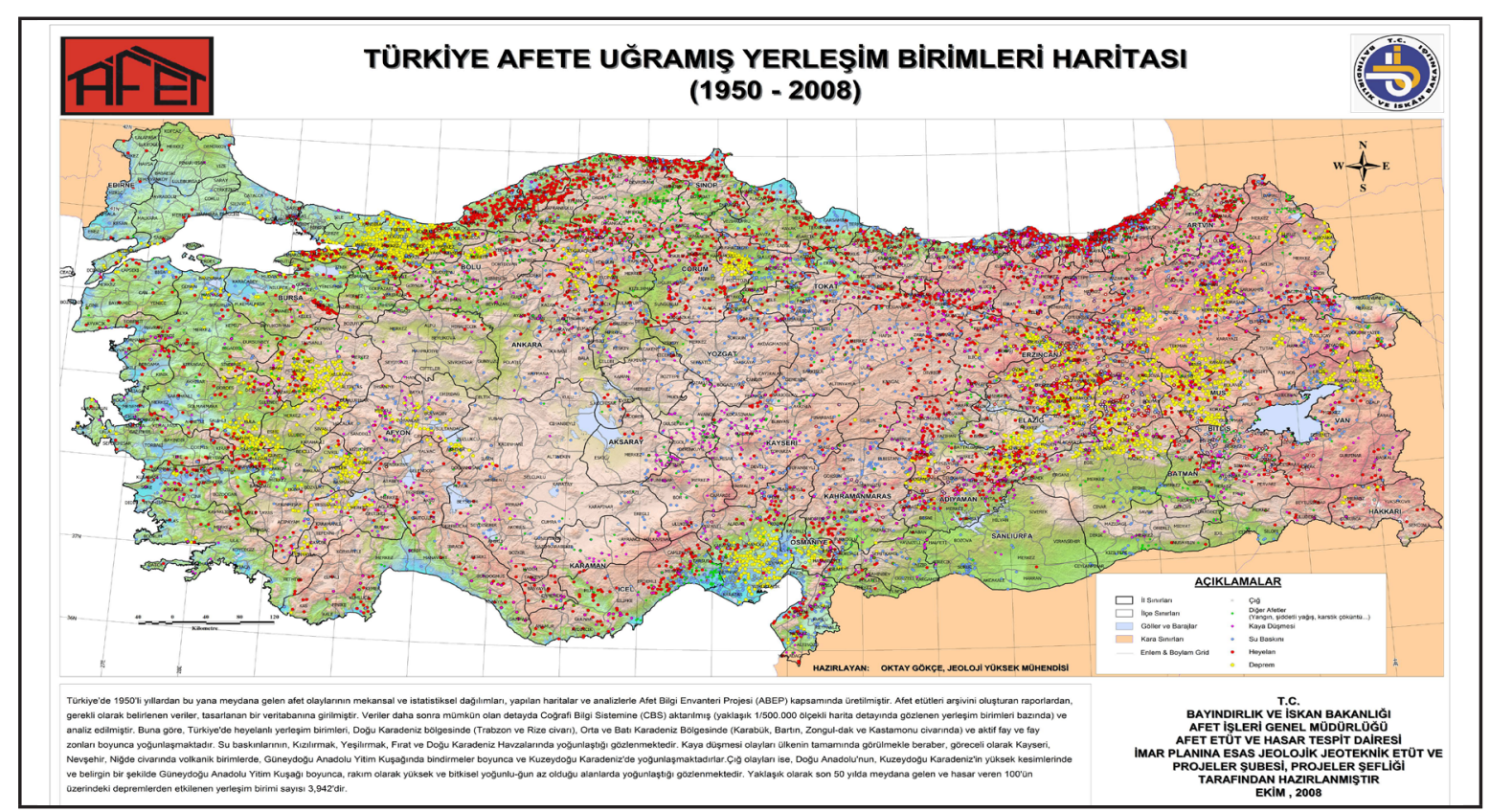

Figure 5. The map of settlements in Turkey suffered disaster between 1950 and 2008. (Gokce et al., 2008)

Each administrative unit in Turkey should be dealt with as an effective disaster management system in terms of the level of risk (Fig. 5). It is necessary to determine the most common types and severity of disasters in the relevant location, as well as the factors that increase disaster severity spatially. If this is implemented, it is obvious that certain disaster-causing incidents can be controlled in a way that benefits the community ahead of time (Koç, Petrow, \& Thieken, 2020). Settlements should be considered not only in terms of geographical location, but also in terms of economic and social influences. With the assistance of certain computer programs and artificial intelligence technologies, the collected data can be analyzed, and spatial risk/danger situations can be reported. The technical assessments and analyses that will be conducted can provide policymakers with critical information.

\section{Conclusion / Discussion}

The framework of crisis management can be adapted to the type, severity, spatial, and changing patterns of potential crises. Officers are periodically appointed to the heads of pro- 
vincial and district units in Turkey. This situation may sometimes result in the risky area not being properly recognized. Even if ideal laws and plans are made in the administrative center, disaster management would be difficult to achieve the desired success unless a spatial disaster arrangement is made for potential disasters. In the case of Turkey, emergency management and the implementation of such procedures have not achieved the desired results in the last 100 years of experience. According to Balamir (2007; Aydner and Özgür, 2014) the model designed from location to center in disaster management would be beneficial in minimizing disaster risks, whereas the command-control model would be more effective in disaster response.

In this context, disaster risk and intensity maps for the location should be prepared. These supplies will help disaster relief efforts in other countries that have experienced similar disasters (Fujita / Shaw, 2019). Besides that, stakeholder engagement is critical for evaluating risks and to ensure social participation in global issues of disaster management (Guo \& Kapucu, 2019). Perić \& Cvetković, 2019).

\section{References}

1. Alexander, D. (2005). Towards the development of a standard in emergency planning. Disaster Prevention and Management, Vol. 14 No. 2, pp. 158-75.

2. Coppola, D. P. (2011). Introduction to International Disaster Management, Elsevier.

3. Aydıner, T., Özgür, H. (2014). Yönetişim ve doğal afetler: Türkiye‘de doğal afet yönetişimi ne kadar hangi biçimde mümkün?, 12. Kamu Yönetimi Forumu, Aydın, s. 395-405.

4. Balamir, M. (2007). Afet Riski ve Planlama Politikaları. TMMOB Afet Sempozyumu Bildiriler Kitabı, TMMOB, Ankara, s. 31-45.

5. Bölük E., Kömüşcü A.Ü. (2018). Köppen-Trewartha iklim sınıflandırmasına göre Türkiye iklimi. Turkish State Meteorological Service (MGM). https://www.mgm.gov.tr/FILES/ iklim/iklim_siniflandirmalari/Köppen-Trewatha.pdf (Accessed 25 April 2021).

6. Cvetković, V. (2019). Risk perception of building fires in Belgrade. International Journal of Disaster Risk Management, 1(1), 81-91.

7. Çakın, O. (2007). Principles of Emergency Management. Afet Yönetimi Ders Notu, Kocaeli.

8. Fujita, K., Shaw, R. (2019). Preparing International Joint Project: use of Japanese flood hazard map in Bangladesh. International Journal of Disaster Risk Management, 1(1), 62-80.

9. Ganapati, N.E. (2008). Disaster management structure in Turkey: away from a reactive and paternalistic approach?, in Pinkowski, J. (Ed.), Disaster Management Handbook, CRC Press, Boca Raton, FL.

10. Gökçe, O., Özden, Ş., Demir, A. 2008. Türkiyede afetlerin mekansal ve istatistiksel dağılımı: afet bilgileri envanteri. [The spatial and statistical distribution of disasters in Turkey: the inventory of disaster information]. Ankara: General Directorate of Disaster Affairs.

11. Guo, X., Kapucu, N. (2019). Examining stakeholder participation in social stability risk assessment for mega projects using network analysis. International Journal of Disaster Risk Management, 1(1), 1-31.

12. Koç, G., Petrow, T., Thieken, A.H. (2020). Analysis of the Most Severe Flood Events in Turkey (1960-2014): Which Triggering Mechanisms and Aggravating Pathways Can be Identified? Water, 12, 1562. https://doi.org/10.3390/w12061562 
13. Kuterdem, K. (2010). A New Disaster Management Structure in Turkey. In 1st Meeting of the European Forum for Disaster Risk Reduction (EFDRR), 6-8 October 2010, Stenungsund, Gothenburg, Sweden.

14. Macit, İ. (2019). Bütünleşik afet yönetiminde Sendai çerçeve eylem planının beklenen etkisi [The Anticipated Effects of Sendai Framework Action Plan in Integrated Disaster Management]. Doğal Afetler ve Çevre Dergisi, 5(1): 175-186.

15. Öcal, A. (2007). İlköğretim okullarında deprem hazırlıkları: Kırıkkale il örneği. Kastamonu Ĕ̈itim Dergisi, 15(1), 1-12.

16. Öcal, A. (2019). Natural disasters in Turkey: Social and economic perspective. International Journal of Disaster Risk Management, 1(1), 51-61.

17. Perić, J., Cvetković, V. M. (2019). Demographic, socio-economic and phycological perspective of risk perception from disasters caused by floods: case study Belgrade. International Journal of Disaster Risk Management, 1(2), 31-45.

18. Petak, W.J. (1985). Emergency management: a challenge for public administration. Public Administration Review, Vol. 45 No. 1, pp. 3-7.

19. Pearson, L., Pelling, M. (2015). The UN Sendai framework for disaster risk reduction 2015-2030: Negotiation process and prospects for science and practice. Journal of Extreme Events, 2(01), 1571001.

20. Sahin S. (2019). The Disaster Management in Turkey and Goals of 2023. Turk. J. Earthq. Res., 1 (2), 180-196

21. Seymen, A., Akın, D. (No date). Disaster management system of Turkey and Lessons Learned from 1999 big earthquakes. (Presentation). Turkish Republic Ministry of Public Works and Settlement, General Directorate of Disaster Affairs. http://www.jst.go.jp/asts/ asts_mon/files/dr_akin/DrAkin_Presentation.pdf Last visited 23.04.2021.

22. Turkish Republic Ministry of Interior's Disaster and Emergency Management Presidency (AFAD). (2018). Turkey earthquake regions map. https://deprem.afad.gov.tr/deprem-tehlike-haritasi (Accessed 25 April 2021).

23. Turkish Republic Ministry of Interior's Disaster and Emergency Management Presidency (AFAD). (2021). About AFAD. https://www.afad.gov.tr/afad-hakkinda (Accessed on 25 April 2021)

24. Turkish Republic Ministry of Interior's Disaster and Emergency Management Presidency (AFAD). (2021). Turkiye Afet Bilgi Bankası [Turkey Disaster Information Bank] (TABB). https://tabb-analiz.afad.gov.tr/ (Accessed on 25 April 2021).

25. Ünlü, A., Kapucu, N., Şahin, B. (2010). Disaster and crisis management in Turkey: A Need for a Unified Crisis Management System. Disaster Prevention and Management, Vol. 19, No. 2, s. 155-174.

26. Yavaş, H., Yavuz, Ö. (2015). Türk afet yönetiminde merkezîleşme sorunu ve yerelleşme çabaları [Centralization problem and decentralization efforts in Turkish Disaster Management]. Yerelleşme / Merkezîleşme Tartışmaları 9. Kamu Yönetimi Sempozyumu Bildiriler Kitabı (7-8-9 Mayıs 2015). TODAİE, 1. Basım, Ankara.

Conflicts of Interest: “The authors declare no conflict of interest.” 